\title{
Satisfaction of combined and exclusive injectable contraceptive users of progestogen and associated factors
}

\author{
Satisfação de usuárias de anticoncepcionais injetáveis combinados e exclusivos de \\ progestágeno e fatores associados
}

Ana Gesselena da Silva Farias' ${ }^{1}$, Adman Câmara Soares Lima², Raquel Ferreira Gomes Brasil², Maria da Conceição dos Santos Oliveira Cunha ${ }^{1}$, Glória Maria Almeida Oliveira² ${ }^{2}$ Escolástica Rejane Ferreira Moura ${ }^{2}$

Objective: to know the satisfaction of users of injectable contraceptives with the methods; identify side effects related to the use and verify association between satisfaction and socio demographic variables, specifications of the injectable contraceptives and side effects. Methods: a cross-sectional study of 52 injectable contraceptives users filling a form. Results: 40 (76.9\%) users reported being satisfied with the injectable contraceptives and $12(23.1 \%)$ were dissatisfied. Type of injectable contraceptive and continuity of use were associated with users' satisfaction $(\mathrm{p}=0.042$ and $\mathrm{p}<0.001$, respectively); the most frequent side effects were weight gain $(32.6 \%)$, amenorrhea (30.7\%), headache (28.8\%), hypo menorrhea $(25.0 \%)$, nausea $(25.0 \%)$ and hyper menorrhea $15.3 \%)$. There was no association between satisfaction and socio demographic variables and side effects, however, users who presented weight gain, amenorrhea, headache, nausea and hyper menorrhea were more dissatisfied. Conclusion: the satisfaction of the user with injectable contraceptives varies with the type of the method and positively influences the continuity of use.

Descriptors: Contraceptive Agents; Patient Satisfaction; Drug-Related Side Effects and Adverse Reactions.

Objetivo: conhecer a satisfação de usuárias de anticoncepcionais injetáveis com os métodos; identificar efeitos colaterais relacionad os ao uso e verificar associação entre satisfação e variáveis sociodemográficas, especificações dos injetáveis e efeitos colaterais. Métodos: estudo transversal com 52 usuárias de anticoncepcionais injetáveis, realizado através de um formulário. Resultados: 40 (76,9\%) usuárias relataram estar satisfeitas com o injetável e $12(23,1 \%)$ insatisfeitas. Tipo de anticoncepcional injetável e continuidade de uso apresentaram associação com a satisfação das usuárias ( $\mathrm{p}=0,042$ e $\mathrm{p}<0,001$ respectivamente); os efeitos colaterais mais citados foram ganho de peso $(32,6 \%)$, amenorreia $(30,7 \%)$, cefaleia $(28,8 \%)$, hipomenorreia $(25,0 \%)$, náusea $(25,0 \%)$ e hipermenorreia (15,3\%). Não houve associação entre satisfação e variáveis sociodemográficas e efeitos colaterais, entretanto, as usuárias que apresentaram ganho de peso, amenorreia, cefaleia, náuseas e hipermenorreia eram mais insatisfeitas. Conclusão: a satisfação da usuária com o anticoncepcional injetável varia com o tipo do método e influencia positivamente a continuidade de uso.

Descritores: Anticoncepcionais; Satisfação do Paciente; Efeitos Colaterais e Reações Adversas Relacionados a Medicamentos.

\footnotetext{
${ }^{1}$ Universidade da Integração Internacional da Lusofonia Afro-Brasileira. Redenção, CE, Brazil.

${ }^{2}$ Universidade Federal do Ceará. Fortaleza, CE, Brazil. 


\section{Introduction}

The most commonly used reversible contraceptive methods in the world are the hormonal ones, especially the combined oral and exclusive progestogen oral contraceptives, followed by the injectable ones in these respective presentations ${ }^{(1)}$. In South Africa, for example, injectable contraceptives are the most used, especially the progestogen-exclusive ones ${ }^{(2)}$.

In Brazil, a study based on data from the National Survey on Access, Use and Promotion of Rational Use of Medicines carried out in 20,404 urban households with prevalence on the use of injectable contraceptives calculated on the basis of the report of women aged 15 to 49 years, detected a prevalence of injecting use of $4.5 \%{ }^{(3)}$.

According to a survey carried out with 50 pregnant adolescents aged 11 to 19 years, accompanied by a basic health unit, the use of injectable contraceptives was reported by $30.0 \%$ of the participants ${ }^{(4)}$. This population cutout shows a specific target group of adolescents with expressive adhesion to injectable drugs, which suggests a prevalence of variable use in a particular age group or even in different geographic locations.

Injectable contraceptives offered by the Brazilian Unified Health System are in the monthly and quarterly presentations. Monthly or combined injectable drugs contain a natural estrogen ester, estradiol, and a synthetic progestogen of 50mg of nor ethisterone plus $5 \mathrm{mg}$ of estradiol valerate. The quarterly or exclusive progestogen injectable drugs contain medroxyprogesterone acetate with a $150 \mathrm{mg}$ deposit, a hormone similar to that produced by the female organism. Its use is indicated in the presence of cardiovascular diseases, smoking associated with age over 35 years, exclusive breastfeeding and obesity, conditions that contraindicate the combined monthly injectable drugs $^{(5-6)}$.

The satisfaction of the users with the contraceptive method is an important factor for the continuation of the method, as well as for its correct use and, consequently, for the less occurrence of the side effects and their greater effectiveness. Some characteristics of injectable contraceptives seem to interfere with users' satisfaction, such as: access to the method (including the application), high efficacy, long duration (dispensing daily control as in oral use), being reversible and presenting few side effects ${ }^{(7)}$.

In this context, nurses play a crucial role, since as a member of the family health strategy, one of the functions of the Family Planning Nursing Consultation is to carry out the consultation of women, men and/ or couples in the informed choice of the contraceptive method, including injectable contraceptives. On this subject, it is necessary to implement public policies for family planning that recognize the potential of nurses to manage contraceptive methods and explain their legal support to assume autonomy in this area of care to which it adds a great contribution ${ }^{(8)}$.

Considering the use of expressive contraceptives and the insertion of nurses in this area of care, we identified the satisfaction of users of these methods as an object of research, elaborating the guiding questions: are users of injectable contraceptives satisfied with the method? What is the side effect related to the method? Is there an association between satisfaction with the use of these methods and socio demographic variables, specifications of injectable contraceptives and side effects?

In view of the above, the present study aimed to know the satisfaction of users of injectable contraceptives with the methods; Identify side effects related to the use and verify association between satisfaction and socio demographic variables, specifications of the injectable drugs and side effects.

\section{Methods}

Cross-sectional study, carried out in a health unit belonging to the Federal University of Ceará, located in the city of Fortaleza, CE, Brazil. This unit functions as a field of practice for nursing students, which offers, among other services to the community, 
assistance to family planning, through nursing consultations and health education actions.

The population was comprised of users of combined injectable contraceptives and exclusive progestogen, monitored in the referred unit. In August 2014, 77 women were followed, with 52 injecting contraceptive users (n=52). Exclusion criteria were: users of injectable contraceptives combined with 30 days or more of use and users of exclusive progestogen injectable contraceptives with 90 days or more of use, as participants would have at least one cycle of exposure to the method.

The interviews were conducted in a private setting, previously selected for this purpose, from November 2014 to April 2015. The subjects' responses were recorded concomitantly by the interviewers. The data collection form was prepared by the authors themselves, with open and closed questions about demographic and socioeconomic aspects, specifications of the injectable drugs (type, time of use and continuity of use), side effects and user satisfaction with methods.

In the evaluation of satisfaction, the users responded to a three-level scale developed by the authors, which defined: satisfied, with no complaints or restrictions regarding the method; partially satisfied, with complaints and/or restrictions on the method, although they continued to use it; and dissatisfied, with complaints and/or restrictions on the use of the method and interest in stopping use. In the analysis of data, the union of the last two categories (partially satisfied and dissatisfied) was considered unsatisfied, because in these categories there is discontent regarding the use of the injectable drugs.

The data were organized in Excel for Windows and analyzed in the Statistical Package for Social Science, version 20.0, license number: 10101131007. A descriptive statistical analysis was performed, based on absolute and relative frequency. The existence or non-existence of an association between the satisfaction of the use of injectable contraceptives and in- dependent variables (socio demographic, time of use, side effects) was verified by applying the Chi-square test or the Fisher's exact test $<0.05$.

The study complied with the formal requirements contained in national and international standards for research involving human subjects.

\section{Results}

Of the 52 participants, 35 (67.3\%) used combined injectable contraceptives and 17 (32.7\%) exclusive progestogen injectable contraceptives. Participants ranged in age from 16 to 41 years, with a predominance of 20 to 34 years old, corresponding to 32 (61.5\%) of the total interviewees. The other 20 (38.5\%) women were at the reproductive ends.

In relation to schooling, 34 (65.3\%) had 10 to 12 years of schooling, demonstrating that these women had at least high school education. The majority had a fixed partner, corresponding to 47 (90.4\%). Participants who declared themselves at home, 36 (69.3\%), followed by 16 (30.7\%) who declared that they had paid work and/or were studying.

Regarding users' satisfaction with the method, 40 (76.9\%) reported being satisfied and 12 (23.1\%) reported dissatisfaction. The time of injecting contraceptives ranged from one month to 13 years. The majority of users (40-76.9\%) reported a time of use of up to one year, corresponding to 19 (36.5\%) users of monthly injectable drugs and 13 (25.0\%) users of quarterly injectable drugs. Most of the interviewees wanted to continue with the method (40-76.9\%).

Almost all users (51-98.0\%) had side effects. The most reported the same for the two types of injectable drugs: weight gain (17-32.6\%), amenorrhea (16-30.7\%), headache (15-28.8\%), hypo menorrhea (13-25.0\%), nausea (13-25.0\%) and hyper menorrhea (8-15.3\%).

The association between user satisfaction and socio-demographic variables and specifications of injectable contraceptives is presented in Table 1. 
Table 1 - Association between user satisfaction and socio demographic variables and specifications of injectable contraceptives

\begin{tabular}{ll} 
Variables $(n=52)$ & \multicolumn{2}{c}{ Satisfied Dissatisfied } \\
\cline { 2 - 2 } & $n(\%) \quad n$ value \\
\hline
\end{tabular}

Age (years)

$\begin{array}{lrrr}\geq 19 & 9(69.2) & 4(30.8) & 0.466^{*} \\ <19 & 31(79.5) & 8(20.5) & \\ \text { Schooling (years) } & & & \\ & & & \\ \text { Until 9 } & 15(83.3) & 3(16.7) & 0.507^{*} \\ 10 \text { to } 12 & 25(73.5) & 9(26.5) & \end{array}$

Occupation

Housewife

Paid work and/or study

$27(75.0) \quad 9(25.0)$

$13(81.2) \quad 3(18.8)$

Marital status

With stable partner

Without stable partner

$36(76.6) \quad 11(23.4)$

$4(80.0) \quad 1(20.0)$

$0.733^{*}$

Specifications

Types of injected contraceptives

Combined contraceptives

$30(85.7) \quad 5(14.3) \quad 0.042^{* *}$

Exclusive prostogen contraceptive

$10(58.8) \quad 7(41.2)$

Time of use (years)

\begin{tabular}{lccc} 
Until 1 & $30(75.0)$ & $10(25.0)$ & \\
$>1$ & $10(83.3)$ & $2(16.7)$ & $0.709^{*}$ \\
Continuity of use & & & \\
Yes & $38(95.0)$ & $2(5.0)$ & $\leq 0.001^{*}$ \\
No & $2(16.7)$ & $10(83.3)$ & \\
\hline Fisher's exact test; **Chi-Square test & &
\end{tabular}

There was no statistically significant difference between the satisfaction of the users and the socio demographic variables. However, the satisfaction was higher among younger women and the ones with less schooling.

Regarding the specifications of the methods, the type of injectable contraceptive used and the continuity of the method were associated with the satis- faction of the users $(\mathrm{p}=0.042$ and $\mathrm{p} \leq 0.001$, respectively). Combined injectable contraceptive users are more satisfied with the use of this method when compared to progestin-only contraceptive users. Regarding the intention to continue injecting, the expressive percentage of women who wished to maintain their use was satisfied (95.0\%), while $83.3 \%$ of women who wished to stop were dissatisfied.

Table 2 reports the associations between user satisfaction and side effects.

Table 2 - Association between user satisfaction and reported side effects

\begin{tabular}{|c|c|c|c|}
\hline \multirow{2}{*}{ Variables (n=52) } & Satisfied & Dissatisfied & \multirow{2}{*}{ p value } \\
\hline & $n(\%)$ & $n(\%)$ & \\
\hline \multicolumn{4}{|l|}{ Side effects } \\
\hline \multicolumn{4}{|l|}{ Weigth gain } \\
\hline Present & $11(64.7)$ & $6(35.3)$ & \multirow[t]{2}{*}{$0.173^{*}$} \\
\hline Absent & $29(82.9)$ & $6(17.1)$ & \\
\hline \multicolumn{4}{|l|}{ Amenorrhea } \\
\hline Present & $11(68.8)$ & $5(31.2)$ & \multirow{2}{*}{$0.478^{*}$} \\
\hline Absent & $29(80.6)$ & 7 (19.4) & \\
\hline \multicolumn{4}{|l|}{ Headache } \\
\hline Present & $9(60.0)$ & $6(40.0)$ & \multirow{2}{*}{$0.081^{*}$} \\
\hline Absent & $31(83.8)$ & $6(16.2)$ & \\
\hline \multicolumn{4}{|l|}{ Hypo menorrhea } \\
\hline Present & $11(84.6)$ & $2(15.4)$ & \multirow{2}{*}{$0.706^{*}$} \\
\hline Absent & $29(74.4)$ & $10(25.6)$ & \\
\hline \multicolumn{4}{|l|}{ Nausea } \\
\hline Present & $9(69.2)$ & $4(30.8)$ & \multirow{2}{*}{$0.466^{*}$} \\
\hline Absent & $31(79.5)$ & $8(20.5)$ & \\
\hline \multicolumn{4}{|l|}{ Hyper menorrhea } \\
\hline Present & $5(62.5)$ & $3(37.5)$ & \multirow{2}{*}{$0.366^{*}$} \\
\hline Absent & $35(79.5)$ & $9(20.5)$ & \\
\hline
\end{tabular}

Even without a statistically significant difference, it was possible to observe that women with weight gain, amenorrhea, headache, nausea and hyper menorrhea were more dissatisfied than women who did not report these adverse events. Only the presence of hypo menorrhea showed the reverse. 


\section{Discussion}

The study presents a limitation, since the results cannot be generalized due to the reduced size of the sample and its development in only one teaching health unit. Their guiding questions can be studied in new research and thus obtain more comprehensive answers.

In relation to the satisfaction of the users of injectable contraceptives with the socio demographic data, there was no statistically significant association. However, it was possible to observe that $30.8 \%$ of adolescents were dissatisfied with the method. Regarding the age of injecting contraceptive users, the majority of the participants $(61.5 \%)$ were of reproductive age that did not represent a reproductive risk and did not constitute a contraindication to the use of these methods. However, $38.5 \%$ were at reproductive extremes, at ages representing reproductive risk. In this regard, it is incumbent on the nurse to guide adolescents and women over the age of 35 about the contraceptive methods available and suitable for each age. It is not known whether the use of exclusive progestogen injectable drugs in adolescents affects maximum bone mass or whether adult women with prolonged use can recover bone mineral density and return to baseline levels before menopause. Alterations caused by the use of exclusive progestogen injectable drugs in bone mineral density during reproductive years and the risk of fractures in the future are not yet known ${ }^{(9)}$.

As for schooling, women with 10 to 12 years of schooling were more unsuccessful than women with fewer years of schooling. This finding may seem contradictory, given that higher schooling favors the apprehension of information about injectable contraceptives, a condition that may promote satisfaction with the use of the injectable, a better understanding of the method, its functioning, and the side effects, among others. On the other hand, this same group of women may demonstrate a greater degree of demand regarding the method, refuting the side effects or the mode of administration, for example, feeling dissatisfied.

Both users with paid work and/or studying as users with fixed partner had lower levels of satisfaction with injectable contraceptives, when compared to those who declared themselves to be housewives and without a fixed partner, respectively. Not having an employment relationship and remaining dedicated only to the work at home may be a less active, less critical stance, which may also justify more satisfaction with the use of injectable contraceptives due to this more passive, more acceptable posture.

A descriptive study, carried out with 20 women accompanied in a reference unit in reproductive care, in Ceará, seized from the participants' point of view, the contribution of partners in family planning was important, since both the act of conceiving and the creation of dependent efforts of the couple, and therefore this planning must be carried out by both. However, some participants demonstrated acceptance of the male absence in this task, and others even disregarded this sharing of responsibilities, assigning only that responsibility to the woman ${ }^{(10)}$. Thus, it is arguable that women with a fixed partner $(90.4 \%)$ can make a shared choice of the use of the injectable with their partner. The shared choice can generate greater security in the user and, consequently, greater satisfaction. However, if there is no complicity of the partner, the user may feel insecure and express dissatisfaction with the method or be indifferent to this lack of participation.

Regarding the specifications of injectable contraceptives (type, time of use and continuity of use), the type of injectable and the continuity of use were associated with the satisfaction of the user in relation to the method. The users of exclusive progestogen contraceptives were more dissatisfied (41.2\%) $(\mathrm{p}=0.042)$.

Regarding continuity of use, the majority of users who reported interest in discontinuing use of the method reported dissatisfaction with the method 
( $\mathrm{p} \leq 0.001$ ). A study carried out in Brazil found that in the presence of a side effect, 12 women waited for the side effect to pass, two used some medication to alleviate adverse effects, 3 stopped using the method and 8 sought a health service for guidelines ${ }^{(11)}$.

Some aspects related to injectable contraceptives interfere with user satisfaction, such as the efficacy of the method, duration and predictability of return of women's fertility ${ }^{(12)}$.

There was no significant relationship between satisfaction and time of use of the method; however, it was found that the majority of injecting contraceptive users for up to one year are more dissatisfied when compared to those who have used the most time. The high continuation rate is related to the users' satisfaction, due to the long usage time. A survey conducted in Nigeria showed that 68 (81.9\%) users of progestin-only contraceptives reported having stopped contraceptive due to menstrual abnormality, five (6.0\%) due to excessive weight gain and four (4.8\%) because they wanted to get pregnant. Therefore, most of the women interrupted the use of the method due to the appearance of side effects being a reason for dissatisfaction $^{(13)}$.

Regarding the side effects and the relationship with the satisfaction of the users, there was no statistically significant association, however, it was possible to verify that women who presented weight gain (35.3\%), amenorrhea (31.2\%), headache $(40.0 \%)$, nausea (30.8\%) and hyper menorrhea (37.5\%) were more dissatisfied.

A study conducted in Iran identified as main side effects, in the group of combined injectable contraceptive users, hypo menorrhea (37.6\%), mood swings $(25.6 \%)$, weight gain $(20.0 \%)$ and headache 14.4\%). Amenorrhea (74.4\%) and weight gain $(48.0 \%)$ were identified in the group of users of progestogen exclusive contraceptive ${ }^{(14)}$.

Side effects may influence the choice of contraceptive methods and use related satisfaction. Research conducted in Brazil identified as the factors that most influenced the choice of method: to have few side effects $(26.5 \%)$ and accessibility $(22.7 \%)^{(11)}$.

Weight gain was the most reported side effect among users, although it did not show a statistical relationship with satisfaction $(\mathrm{p}=0.173)$. In this sense, it is important that the woman acts actively in weight control, performing regular physical activity and having a healthy and balanced diet ${ }^{(5)}$.

Overall, almost all users (98.0\%) reported side effects. It is observed that the prevalent side effects among users of injectable contraceptives are related to changes in menstrual flow.

Therefore, the fundamental role of the nurse in the promotion and follow-up of the use of injectable contraceptives is confirmed, when she is informed to the woman about the side effects and how to deal with them. This nursing care will reduce the fear and insecurity of the users and provide better observation of the side effects, greater persistence in the continuity of use of the method and greater satisfaction with the use $^{(15)}$.

It is noteworthy that despite dissatisfaction with the contraceptive method, the users interviewed would recommend the method to other women.

The results provide contribution to the professional practice of nursing and to the health service in family planning that the use of injectable contraceptives can bring dissatisfaction and interfere in the continuity of the use of the method. It is reiterated that nurses need to be able to take on family planning activities with autonomy, highlighting the clinical follow-up of the users of injectable contraceptives, orientation on the choice of method, its side effects and how to deal with them ${ }^{(11)}$.

\section{Conclusion}

There was a predominance of injecting contraceptive users satisfied with the method (76.9\%). women who presented weight gain (35.3\%), amenorrhea (31.2\%), headache (40.0\%), nausea (30.8\%) and 
hyper menorrhea (37.5\%) were mostly dissatisfied. There were factors associated with the satisfaction of injecting contraceptive users with the method: type of contraceptive and continuity of use, with the highest percentages of dissatisfaction among users of exclusive progestogen injectable contraceptives, who showed an interest in not continuing the use.

\section{Collaborations}

Farias AGS, Lima ACS, Brasil RFG and Moura ERF contributed in designing the project, analyzing, interpreting the data and critically reviewing the intellectual content. Cunha MCSO and Oliveira GMA contributed in the final approval of the version to be published.

\section{References}

1. Urban M, Banks E, Egger S, Canfell K, Connel OD, Beral VSF. Injectable and oral contraceptive use and cancers of the breast, cervix, ovary, and endometrium in black South African women: casecontrol study. PLOS Med [Internet]. 2012 [cited 2016 Apr 10]; 9(3):1-11. Available from: http:// www.plosmedicine.org/article/fetchObject. action?uri=info\%3Adoi\%2F10.1371\%2Fjournal. pmed.1001182\&representation=PDF

2. Hofmeyr GJ, Singata-Madliki M, Lawrie AT, Bergel E, Temmerman M. Effects of the copper intrauterine device versus injectable progestin contraception on pregnancy rates and method discontinuation among women attending termination of pregnancy services in South Africa: a pragmatic randomized controlled trial. Reprod Health [Internet]. 2016 [cited 2016 Apr 10]; 13(42):2-8. Available from: https://www.ncbi. nlm.nih.gov/pmc/articles/PMC4835872/

3. Farias MR, Leite SN, Tavares NUL, Oliveira MA, Arrais PSD, Bertoldi AD, et al. Utilização e acesso a contraceptivos orais e injetáveis no Brasil. Rev Saúde Pública [Internet]. 2016 [citado 2017 mai. 30]; 50(supl 2):14s. Disponível em: http://www. scielo.br/pdf/rsp/v50s2/pt_0034-8910-rsp-s2S01518-8787201605000SUPL2AP.pdf
4. Duarte CF, Holanda LB, Medeiros ML. Avaliação de conhecimento contraceptivo entre adolescentes grávidas em uma unidade básica de saúde do Distrito Federal. J Health Sci Inst [Internet]. 2012 [citado 2017 mai. 30]; 30(2):140-3. Disponível em: https://www.unip.br/comunicacao/publicacoes/ ics/edicoes/2012/02_abr-jun/V30_n2_2012_ p140-143.pdf

5. Ministério da Saúde (BR). Saúde sexual e saúde reprodutiva. Brasília: Ministério da Saúde; 2013.

6. Singhal S, Sarda N, Gupta S, Goel S. Impact of injectable progestogen contraception in early puerperium on lactation and infant health. J Clin Diagn Res [Internet]. 2014 [cited 2016 Apr 10];8(3):69-72. Available from: https://www. ncbi.nlm.nih.gov/pmc/articles/PMC4003690/

7. Tsehaye WT, Mengistu D, Birhanu E, Berhe KK. Assessment of preference and its determinant factors to ward modern contraceptive methods among women of reproductive age group in shire Indaselassie Town, northern Ethiopia, 2011. Int J Family Med [Internet]. 2013 [cited 2016 Apr 20]; 1-8. Available from: www.ncbi.nlm.nih.gov/pmc/ articles/PMC3874318/pdf/IJFM2013-317609

8. Dombrowskil JG, Pontes JA, Assis WALM. Atuação do enfermeiro na prescrição de contraceptivos hormonais na rede de atenção primária em saúde. Rev Bras Enferm [Internet]. 2013 [citado 2017 mai. 30]; 66(6):827-32. Disponível em: http:// www.scielo.br/scielo.php?script=sci_arttext\&pid=S0034-71672013000600003

9. World Health Organization. Medical eligibility criteria for contraceptive use. Geneva: World Health Organization; 2015.

10. Morais ACB, Cruz RSBLC, Pinto SLP, Amorim LTCG, Sampaio KJAJ. Participação masculina no planejamento familiar: o que pensam as mulheres? Cogitare Enferm [Internet]. 2014 [citado 2017 mai. 30]; 19(4):659-66. Disponível em:http://revistas.ufpr.br/cogitare/article/ view/37086/23901

11. Zunta RSB, Barreto ES. Planejamento familiar: critérios para escolha do método contraceptivo. J Health Sci Inst [Internet]. 2014 [citado 2017 mai. 30]; 32(2):173-8. Disponível em: https:// www.unip.br/comunicacao/publicacoes/ics/ edicoes/2014/02_abr-jun/V32_n2_2014_ p173a178.pdf 
12. Tolley EE, Mckenna K, Mackenzie C, Ngabo F, Munyambanza E, Arcara J, et al. Preferences for a potential longer-acting injectable contraceptive: perspectives from women, providers, and policy makers in Kenya and Rwanda. Global Health Sci Pract [Internet]. 2014 [cited 2016 Apr 10]; 2(2):182-94. Available from: https://www.ncbi. nlm.nih.gov/pmc/articles/PMC4168623/

13. Adeyemi AS, Adekanle DA. Progestogen-only injectable contraceptive: experience of women in Osogbo, southwestern Nigeria. Ann Afr Med [Internet]. 2012 [cited 2016 Apr 20]; 11(1):27-31. Available from: http://www.ajol.info/index.php/ aam/article/viewFile/73896/64573
14. Veisi F, Zangeneh M. Comparison of two different injectable contraceptive methods: depo-medroxy progesterone acetate (DMPA) and cyclofem. J Fam Plann Reprod Health Care [Internet]. 2013 [cited 2016 Apr 20]; 7(3):109-13. Available from: https://www.ncbi.nlm.nih.gov/pmc/articles/ PMC4064779/

15. Américo CF, Nogueira PSF, Vieira RPRV, Bezerra CG, Moura ERF, Lopes MVO. Knowledge of users of low-dose oral combined contraceptives about the method. Rev Latino-Am Enfermagem [Internet]. 2013 [cited 2017 May 30]; 21(4):928-34. Available from: http://www.revistas.usp.br/rlae/article/ view/76005/79602 